\title{
on_education
}

\section{Critique in the Age of Trump}

\section{Christopher Castiglia (Pennsylvania State University)}

\begin{abstract}
:
This article argues that the practices of critique have naturalized the political strategies deployed by Donald Trump and his European counterparts. At its extreme in current 'call out' politics, the tendencies of critique - the clear and absolute oppositions between right and wrong, the vilification of those who find themselves on the opposite side than the critic, the tendency to locate such oppositions within identity discourses - have emerged in the Trump era as the vicious, ad hominem, anti-dialogic strategies that mark both the Right and the Left.
\end{abstract}

Keywords:

calling out culture; criticism; Donald Trump; post-critique

For several years now I have been part of a community of scholars advocating for a 'post-critique' criticism. I wrote a book, The Practices of Hope: Literary Criticism in Disenchanted Times, in which I endorsed a "dispositional shift” (Castiglia, 2017, pp. 10-13) in critical studies away from what Eve Sedgwick famously called "paranoid reading," that is, the assumption that nefarious ideologies, identified as a text's 'real' meaning, hide beneath an obfuscating surface, requiring critics to unmask and expose them (Sedgwick, 1997). In place of such paranoid reading practices, I argued that 'post-critique' criticism offers ways for our work to become more imaginative, inventive, and even idealistic. Four years ago, when I published that book, I felt - or hoped - that the era of critical paranoia was coming to an end and that we were on the brink of what Sedgwick called a "reparative” moment in criticism (Sedgwick, 1997).

Looking back now, I see that my hopes for a 'postcritique' criticism underestimated how entrenched and naturalized the practices and assumptions of paranoid reading had become through three generations of classroom instruction. Undergraduates and especially graduate students in the humanities today have been trained for years in 'critique' not as $a$ way of reading but as the way, so much so that they understand 'critique' as synonymous with reading itself. The parameters of paranoid reading - its clear-cut opposition between right and wrong, victim and oppressor, for example - have become ingrained to the point of dogma, and students have accepted (uncritically, I would argue) the rote truth-claims of critique as a way of seeing not only literary and cultural texts but the broader social world. The endless rehearsal of the methods of critique has naturalized (made uncriticizable) the belief that there are clear divisions between good and bad ideological positions - that neither texts nor society are made messy by mixed motives, conflicting interests, unpredictable complicities - and that those ideologies are embodied by good and bad kinds of people, who, like the ideological positions they represent, are to be unmasked and judged by the critic. Built in to critique, then, is not only paranoia, but intolerance, both toward any recognition that texts and characters in texts are complex and, insofar as texts are said to represent 'politics' in the 'real world,' also toward diversity among the readers of texts. For readers to fail to identify with characters marked as virtuous in the text, or, worse, to warm to characters critiqued as insidious, or, more fundamentally, to disagree with disciplinary assumptions about a text's purportedly clear distinctions between right and wrong, complicity and liberation, is strongly discouraged in an academic context. At best, such readings - and those who venture them - are dismissed as frivolous. Usually, both are condemned using the same standards that were used to criticize the texts themselves. These dynamics arise especially - indeed, almost exclusively - around the identity categories favored in American academia today, a litany of raced and gendered (never classed) terms acutely specific to this time and place, though contemporary critical practices encourage their uncritical application to other times and places. This is what we have taught students of literary criticism, and we present it not as subjective interpretation but as objective truth.

Perhaps a less hopeful reader than the author of Practices of Hope might have recognized how deeply ingrained the habits of thought associated with critique had become. What I don't think anyone could have foreseen, however, was how the rise of 'post-critique' among American scholars coincided with the hopefulness associated with Barack Obama's first election as President of the United States, and 
how the attitudes and assumptions of paranoid reading would be energized by an increasingly polarized post-Obama political climate that both reflects and amplifies critique's dualistic methodologies. Today, we are dealing, in the American academy - and American culture at large - with something worse than the critical paranoia Sedgwick bemoaned. Manichean thinking accompanied by the ideological self-satisfaction that comes with rejecting alternative points of view has resulted, in the humanities, in a dogmatic, censorious, bigoted, and affectively overheated approach to intellectual culture that has had and will continue to have a chilling - if not fatal - effect on the kinds of explorative, experimental, inventive, and constructive readings post-critique advocates call for. This movement is limiting what can be said in humanities classrooms, academic departments, publishing houses, and journals.

These trends are part of a redefinition of institutional and critical 'politics,' which, in former US President Barack Obama's chastening words, center on the belief that "the way of me making change is to be as judgmental as possible about other people" (Rueb \& Taylor, 2020). Obama goes on to characterize what others have described as social media “virtue signaling” (Rueb \& Taylor, 2020):

Like if I tweet or hashtag about how you didn't do something right, or used the wrong verb, then I can sit back and feel pretty good about myself because: 'Man, did you see how woke I was? I called you out.' (Rueb \& Taylor, 2020)

Obama's concerns were echoed and amplified in an open letter to Harper's Magazine published on July 7, 2020, and signed by such cultural leaders as Margaret Atwood, Gloria Steinem, Salman Rushdie, and Bill T. Jones (Ackerman et al., 2020). They describe the threat to freedom of expression brought about by "ideological conformity" and urge that resistance to social injustice "must not be allowed to harden into its own brand of dogma or coercion," since the "free exchange of information and ideas, the lifeblood of a liberal society, is daily becoming more constricted. While we have come to expect this on the radical right," they continue, "censoriousness is also spreading more widely in our culture" along with "an intolerance of opposing views, a vogue for public shaming and ostracism, and the tendency to dissolve complex policy issues in a blinding moral certainty" (Ackerman et al., 2020, para. 2). "More troubling still," they write, "institutional leaders, in a spirit of panicked damage control, are delivering hasty and disproportionate punishments instead of considered reforms." The result is the silencing of those who appear to "depart from the consensus, or even lack sufficient zeal in agreement” (Ackerman et al., 2020, para. 2).
The current danger described by these prominent figures cannot be laid entirely at the feet of literary and cultural critics, of course. But we play a part in it. The forms of criticism nurtured or suppressed in our classrooms, conferences, and publications reflect and reinforce the political tones, attitudes, and strategies of the broader culture. Literary 'critique' has taken on the strategies and attitudes of the current political climate, reflecting the censorious and oppositional forms of suppression described in the Harper's letter. There is an insistence that authors and fictional characters be assessed as exemplary of categories in an oppositional model of identity politics. Related to that, the pursuit of simplistic forms of binary judgment, in which the identification of texts or authors as 'problematic' (once a term of approbation for those who valued complexity) leads immediately to calls for those texts or authors to be removed from the classroom. We are close to seeing the elimination of the aesthetic as a category of criticism altogether. Genuine diversity of experience and opinion - not to mention the intellectual and aesthetic pleasures of encountering difference - are rigorously ruled out of this model in which any slippage between interpretation and prescribed meaning must be rigorously rooted out. This pattern will seem too familiar to anyone teaching in the humanistic disciplines in the United States at the moment.

What I am suggesting is that the reason the signers of the Harper's open letter decry censorship from both the Right and the Left has something to do with the ways the Left has come to reproduce the worst attributes of the Right, particularly as reflected in the US Presidency of Donald Trump and of his European counterparts. Under Trump, who has made divisive politics the new normal, those who disagree with him become enemies, and the media through which those 'enemies' express their opinions are put under siege. The Right generates its own 'facts,' which cannot be questioned. Those on the Right vilify the idea of institutions, while relying on the institutions they control to mete out rewards for loyal followers and punishments for those who dissent. Name-calling has replaced dialogue, as people are divided along identity lines and social media has become a tool for intimidating into silence anyone who would dissent from truth-claims.

Intellectual culture in the age of Trump replicates the tactics of those it nominally opposes. 'Call out' strategies have repeatedly refused civil dialogue in favor of right-andwrong assertions of dramatically opposed positions. When those doing the 'calling out' do not meet with immediate validation, they take to social media, stirring up groups of the angry like-minded to denounce the accused in the most vicious and ad hominem terms. Demands are made that the accused party be silenced, rather than debated, and that silencing take on the force of administrative power. The 
battle is most often fought over identity positions (trans versus cis, black versus white, and so on), for one side of which someone makes indisputable truth-claims. The less willing the called-out parties are to self-censor, the louder the denunciations become, in person and over social media. The result is a 'chilling' of intellectual freedom. The enraged enforcement of dogmatic positions has already, as the signers of the open letter warn it will, turned us away from debates grounded in facts or logic, and replaced discussion with accusation, vilification, enforced conformity, and censorship. The humanities - particularly literary and cultural studies have informed and replicate those politics so seamlessly because they were already, in a milder form, the strategies of 'paranoid reading.'

What seems particularly sad to me is how often 'cancel critics' have attacked scholars whose teaching and scholarship have been informed by feminist, queer, and antiracist theory. This makes a kind of poignant sense. The new good vs. bad logic relies on very clearly demarcated identity categories presented in binary terms. Those identities are defended in terms of their 'authenticity,' a rhetoric in which there are authorized and false (or oppressive) ways of occupying or discussing identities, their representations, and their histories. Fixed and supposedly knowable categories of man and woman, black and white, trans and 'cis' (the latter, a category of supposed alignment with gender roles that queer theory argued no one actually occupies), have animated the rage that turns against scholars who argued for the indeterminacy of identity categories, for the exchanges of cultures across identities, and for the pleasures and powers of resisting and reimagining the clear binaries so characteristic of academic discourse today. One might think of Judith Butler's Gender Trouble (1990), which argued for the performativity of gender, or Eve Sedgwick's Epistemology of the Closet (1990), which positioned 'queerness' as a deconstructive undoing of the homo/hetero binary.

Michel Foucault is another figure who has fallen from critical favor. He had to, for his analyses of the disciplinary procedures that produce and police norms of authenticity describe the dynamics by which those who claim to speak for various identities regularly enlist scientific vocabularies and institutional authorities in order to silence and exclude critics who question the powers constructed through truth-claims about legitimacy and illegitimacy, authenticity and its failures. Today's claims for real gender and sexual identities have made work like Foucault's, Butler's, and Sedgwick's into conservative opponents to the correctness of identity. We have seen the abandonment of identity as a source of play in a discourse of grievance that can allow neither play nor ambiguity.
At times, it may seem like the disputes between critiquers and post-critiquers are big battle over small stakes. But what is happening in academia (and beyond) now shows otherwise. As the writers of the Harper's open letter state, "we need a culture that leaves us room for experimentation, risk taking, and even mistakes" (Ackerman et al., 2020, para. 3 ). These are what post-paranoid forms of criticism might allow. More importantly, these values are essential to the creativity, inventiveness, and diversity that were once thought - and still are by many, although many, in the current climate, also feel hesitant to say so - to constitute the core values of the humanities, and brought students into our classes to read literature and debate critical theories that opened up new horizons.

I want to be clear here that I am opposing the strategies taken up by some on the Left, not the struggles for which they are deployed. As the writers of the open letter stress, this is a moment when we must be most firm about the need for justice and freedom in the face of prejudice and intolerance. How to make a different kind of politics - in which complexity is not complicity, in which ambiguity is openness, in which surprise is welcome and there is pleasure in discovering the diversity of human experiences and desires - is a challenge that the current political moment demands that we take up. And there are models for what a fierce politics of pleasure, queer openness, and play might look like in the past, in the AIDS activism of ACT UP (AIDS Coalition to Unleash Power), to take just one example. It is a mistaken assumption that such play and pleasure are antithetical to political activism. Rather we might see the present moment as calling for an activism more aligned, if you will, with reparative reading than with paranoid critique.

More than ever now, then, it is important to try to move past critique. I hope that, despite the odds, it may still be possible that whatever lies beyond paranoid reading will introduce a different - more tolerant, creative, and tentative - set of values into our classrooms, our intellectual communities, and the broader culture. As part of a postcritique pedagogy and politics, we can be mindful of what histories our intellectual attitudes and strategies arise from, and what values they respond to, against whom they're directed, and to what ends. We can defend the principles of open debate and free discussion on which real education should be built. We can keep scholarship that revolutionized the academy from being vilified and silenced. We can continue our critique of critique, seeing now to what failing to do so can lead. We can reject the political strategies of the day, attempt something more generous, curious, and, as Sedgwick would have it, reparative. 


\section{References}

Ackerman, E., Ambar, S., Amis, M., Applebaum, A., Arana, M., Atwood, M., Banville, J., Bay, M., Begley, L., Berkowitz, R., Berman, P., Berman, S., Betts, R. D., Blair, N., Blight, D. W., Boylan, J. F., Bromwich, D., Brooks, D., Buruma, I. (...) Zakaria, F. (2020, July 7). A letter on justice and open debate. Harper's Magazine. https://harpers.org/a-letter-on-justiceand-open-debate/

Butler, J. (1990). Gender trouble. Routledge.

Castiglia, C. (2017). The practices of hope. Literary criticism in disenchanted times. New York University Press. https://doi.org/10.18574/9781479820030

Rueb, E. S., \& Taylor, D. B. (2020, August 10). Obama on call-out culture: ‘That’s not activism’. The New York Times. https://www.nytimes.com/2019/10/31/us/politics/obama-woke-cancel-culture.html

Sedgwick, E. K. (1990). Epistemology of the closet. University of California Press.

Sedgwick, E. K. (1997). Paranoid reading and reparative reading; or, you're so paranoid, you probably think this introduction is about you. In E. K. Sedgwick, Novel gazing: Queer readings in fiction (pp. 1-37). Duke University Press. https://doi.org/ 10.1215/9780822382478-001

\section{Recommended Citation}

Castiglia, C. (2020). Critique in the age of Trump. On Education. Journal for Research and Debate, 3(9). https://doi.org/10.17899/on_ed.2020.9.9

About the Author

Christopher Castiglia is Distinguished Professor of English at the Pennsylvania State University. He is the author of several monographs, including, most recently, The Practices of Hope: Literary Criticism in Disenchanted Times. 